$\left(\begin{array}{l}\text { J.Soc.Cosmet.Chem.Jpn. } \\ \text { 報 } \\ 29(4) 387-393(1996)\end{array}\right)$

触覚機能を持つロボット型測定装置の開発と応用（第 3 報）†

\author{
飯田一郎 $\dagger^{2}$, 田村あき江 $\dagger^{2}$, 水谷智恵子 $\dagger^{2}$, 野吕影勇 $\dagger^{3}$ \\ 株式会社コーセー $\dagger^{2}$ \\ 早稲田大学 人間科学部融
}

\begin{abstract}
本研究では, まず皮虐生理状態の診断情報を解析するために, 被験者 20 名に対して評価者による触 診・視診評価を実施した。

主成分分析による評価項目間共分散の解析によって, 触覚情報として, なめらかさ因子と弾性因子の 二つの指標が導出された。次に化粧品の使用感評価の観点から, 触知覚モデルを工学的実現するための, ロボットを応用した測定方法を開発した。以上の測定装置を, まずフェイシャルマッサージの効能評価 に適用し, 高年齢層に打いては, 週 1 回 4 週間の施術の継続によって, 皮膚弾力性の改善が認められた。 次に本装置を乳液の感触の測定に応用した。4 種の使用感夕イプの乳液を被験者 4 名の皮䖉に塗布し, 滑り反応を特性值として検出した。

以上の実験結果を解析した結果，乳液の感触に対応した皮䖉表面状態の変化が検出した。
\end{abstract}

\section{1. 緒言}

フェイシャルトリートメントに求められる使用 効果は, 使用直後の皮虐のしっとり感や柔軟性の 向上から, 習慣的な継続使用効果による皮膚の柔 軟性や弾力性や弾力性の改善まで様々である。 例えばフェイシャルマッサージは, 皮膚を柔軟に し, 表情筋を和らげ, 肌の加齢変化 ${ }^{1,2)}$ に対して 有効であると考えられている。一方, 乳液や化粧 水は, ヒトの顔面の皮膚に塗布されて, 皮虐に不 足した水分や脂質を補う役割をもつ。トリートメ ントシステムは生活環境や習慣に応じて, 各年齢 や季節に応じた設計が必要となる。

これらの効能効果は生活者の実感によって評価 されるが，この過程では触覚による認知は重要な 位置づけにある。触覚情報を客観化するために各 種力学的測定が開発されているが，実際の触診や 官能評価とのギャップは埋められていない。以上

\footnotetext{
$\dagger^{1} \quad 1995.4 .12$ 受理

$\dagger^{2}$ 于114 北区栄町 48-18; 48-18 Sakae-cho, Kita-ku, Tokyo, 114 Japan

$\dagger^{3}$ †359 所沢市三ヶ島 2-579-15；2-579-15 Mikashima, Tokorozawa,Saitama 359 Japan
}

の観点から, 前報ではやわらかさ触診の動作解析 を基本とした評価のモデル化を行い，ロボットを 応用した皮膚の力学的計測法を開発した”。

本報では，やわらかさやしっとり感のような多 くの皮膚表面評価における項目間の関係を解析し, 総合指標に対応したロボットによる皮膚表面触感 の測定方法を開発した。本測定法の応用によって 第一に肌のやわらかさ, 弾力性の計測をフェイシ ヤルトリートメントの効能評価に適用し, 継続使 用の改善効果を立証すること，第二に乳液の使用 感に対応した計測情報を得ることを本研究の目的 とした。

\section{2. 測定方法の開発}

\section{1 触覚情報の分類}

被験者 20 名は20 25才で, 女性 11 名, 男性 9 名から構成される。実験過程においては，洗顔 $\rightarrow$ 視診 $\rightarrow$ 触診の順に実施した。被験者の肌状態を安 定させるために, 洗顔後 30 分間は安静な状態を 保ち, その後煩部の視診 (顔色, くすみ, つや, はり，しみ，毛穴，二キビ，キメ等）, 触診 (やわ らかさ, 弾力性, なめらかさ, カサッキ, しっと り感), 機器評価 (水分計, 油分計) を実施した。 
評価項目は合計 20 で，各評価は全て 5 段階評 価によって実施した。触診者は専門家 1 名を設定 した。

20 名 $\times 20$ 項目の実験データに対しては, 分散 共分散行列による主成分分析を実施した。解析ソ フトウェアは日本科学技術研修所の JUSE-MA 1 を使用した。

寄与率は第 1 主成分が $37 \%$ と高く, しっとり 感・なめらかさと対応していた。第 2 主成分は二 キビ等, 第 3 主成分は弾力性・柔軟性等の項目に 対応していた。以上より, 触覚情報に対応してい ると考えられる因子負荷量のプロットは第 1 . 第 3 主成分の布置を Fig.-1に示した。寄与率の 合計は $48 \%$ になる。因子負荷量のプロットによ ると，第 1 主成分で因子負荷量が大きいのはスべ スベ感, カサカサ感, しっとり感, キメ, つゃ等 で, 第 2 主成分で因子負荷量が大きいのは弾力性, 柔軟性，はりである。このことから第 1 主成分は 肌の表面の滑り因子(smooth-rough), 第 3 主成分は 弾性因子(elastic-less elastic)を表す軸であると考 えられ, 触覚情報を分類するための総合指標とし て用いた。触知覚モデルは以上二つの因子につい て検討した。

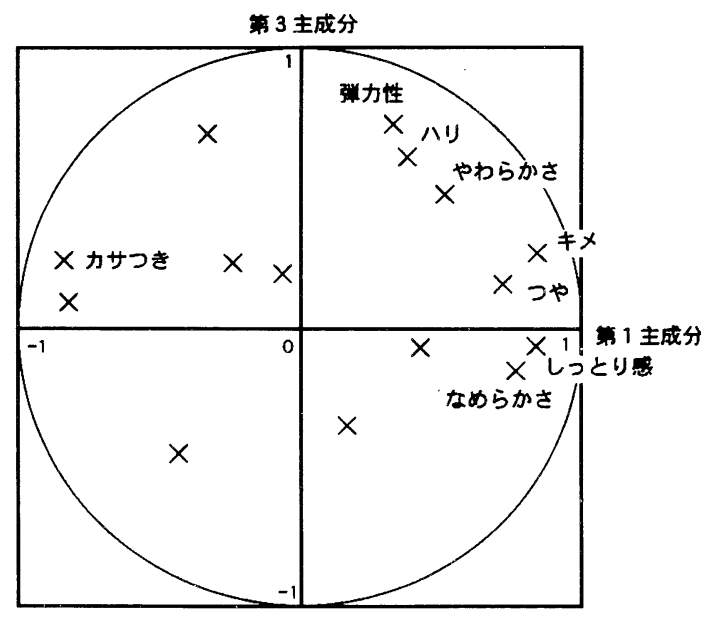

Fig.-1 Factor loading plot of evaluation items

\section{2 触知覚モデルの設定}

触診においては手指を肌に垂直方向と水平方向
に動かす場合が存在し，柔軟性，弾力性は肌に垂 直方向, なめらかさ，しっとり感は肌に水平方向 の触運動が想定される4),5)。肌表面評価の触知覚 モデルを Fig.-2に示した。

a) やわらかさと弾力性

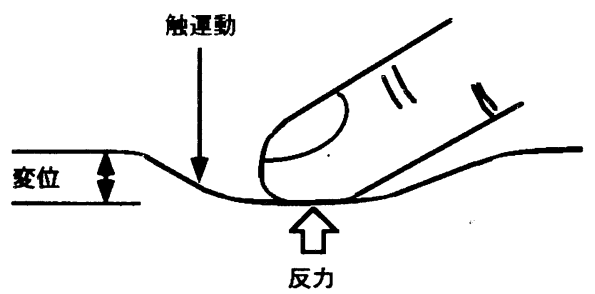

b) なめらかさとしっとり或

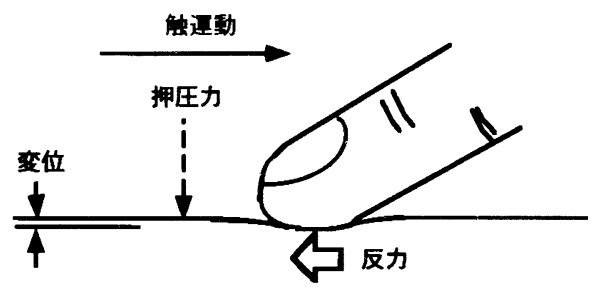

Fig.-2 Perception models of tactile evaluation

やわらかさ・弾力性の触知覚モデルにおいては, 対象物に 3 8mm程度び変位が入力され, 垂直運動 時の反力が応答として検出される。更に弾力性評 価においては, 申し込み時の保持時間と変位の増 大が観測される。一方，しっとり感・なめらかさ の触知覚モデルにおいては, 対象物に 10 20 gf 程度の抗力（接触押圧力）が入力され, 水平運動 時のせん断力（反力）が応答として検出される。 更にしっとり感知覚では, 押し動作が同時に出現 し，滑り動作に扔ける抗力の増大がみられている。 このことは，しっとり感知覚においては弾性因子 と滑り因子のセンシング情報が融合されているこ とを示唆している。

\section{3 測定システム}

装置の設計階段においては, 以上の感知覚モデ ルに基づいて, 触覚センサー, ロボットからなる システム構成について検討しだ”。 
センシング部分においては，水平反力と垂直方 向の反力を同時に検出する必要があり，2 軸のス トレンゲージを設計開発した。

可動部は多関節型で，直交座標系での制御が可 能である三菱電機製 Movemaster RV-M 1 とハー モニックドライブ社製リニアアクチュエータ(LA -30-10-F)を適用した。可動部は, 触子を処理シ ステムにおける出力情報に従って可動させ，皮虐 への接触状態を測定の初期条件として設定し，皮 膚に一定押し圧力を与えた後に，垂直・水平方向 へ可動する役割を持つ。

以上測定機器の構成を Fig.-3に示した。

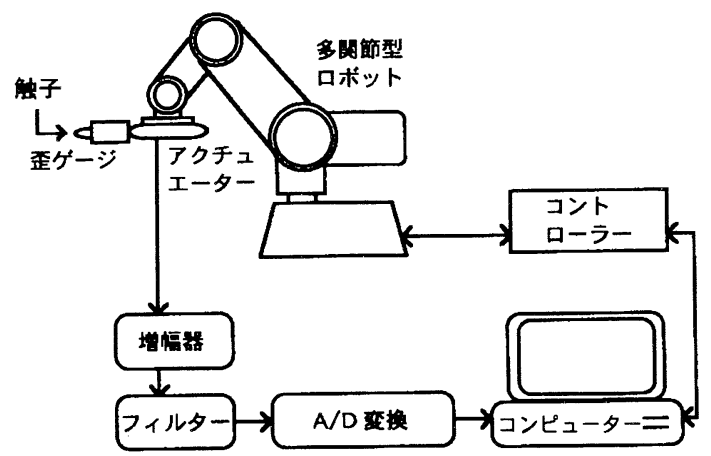

Fig.-3 Components of the measuring system

被験者は座位の状態に設定され，顎台で顔面は 固定される。測定においては，初期位置設定後， 触子が設定されたストローク量だけ移動し, 同時 に二軸方向の反力が検出される。

\section{3. フェイシャルマッサージの効能評価}

\section{1 計測方法}

本実験では，肌に対して垂直方向にプローブを 押し込み， 2 秒間保持することによって，Fig.-4 のような反力曲線を検出した。プローブの可動条 件としては, 触運動分析より抽出したストローク $5.0 \mathrm{~mm}$ ，スピード $12 \mathrm{~mm} / \mathrm{sec}$ を設定した。力学的パ ラメータとして, 押し込み後の反力の最大值 $(\mathrm{MAX})$, 保持 2 秒後の反力值 $\mathrm{H}$ と $\mathrm{MAX}$ の比率 $(\mathrm{H} /$ MAX)を用いた。MAXとやわらかさ（やわらか さの増加に対して, MAX 值は減少する), H/MAX

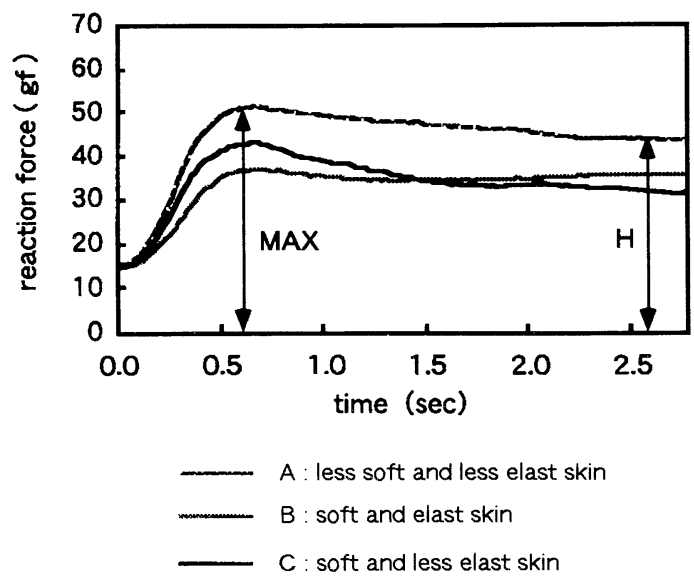

Fig.-4 Change of reaction force human skin during and after pressed by probe

と弾力性（弾力性の増加に対して，H/MAX 值は 増加する）の関連と代用値としての吟味は, 前報 で行った。

\section{2 トリートメント方法}

トリートメントシステムは施術者によるクレン ジング, フェイシャルマッサージ, パックより構 成される。実験の手続きにおいては, 反力測定 $\rightarrow$ 施術一反力測定の順に実施した。

トリートメント実施期間としては週 1 回の頻度 で 4 週間に, 計 5 回のトリートメントを行った。 以上の実験を被験者 20 名(20才〜 50 才の女性)

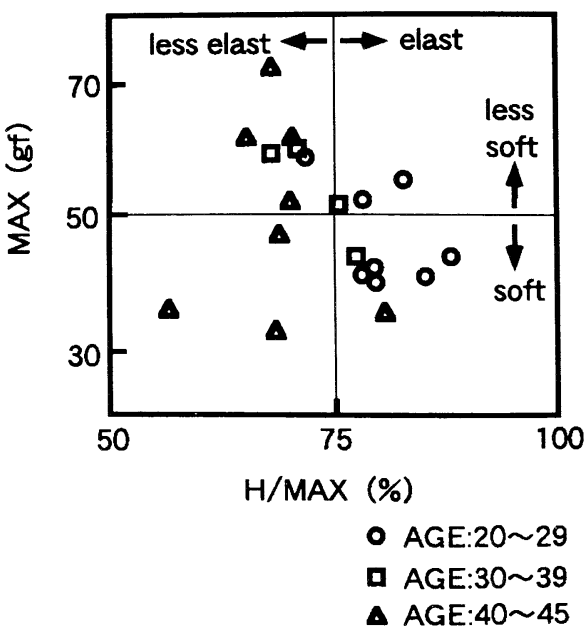

Fig.-5 Dynamic parameters of each panelists 
について実施した。3.1.に示した計測をトリート メント前後に㚘部に対して実施した。

Fig.-5に被験者 20 名の測定結果を示した。

この結果より, 被験者を低柔軟性群と高柔軟性 群，または低弾力性群と高弾力性群に分類した。

\section{3 結果と考察}

Fig.-6に 1 回目の施術における MAX 值の変化 を, Fig.-7に5回の施術毎の変化を, 柔軟性指 標で層別した二群について示した。

Fig.-6において, 施術前と施術直後の MAX 值 を比較すると, 柔軟性の低い群において MAX 值 の増加がみられ, 有意差が検出されている。この

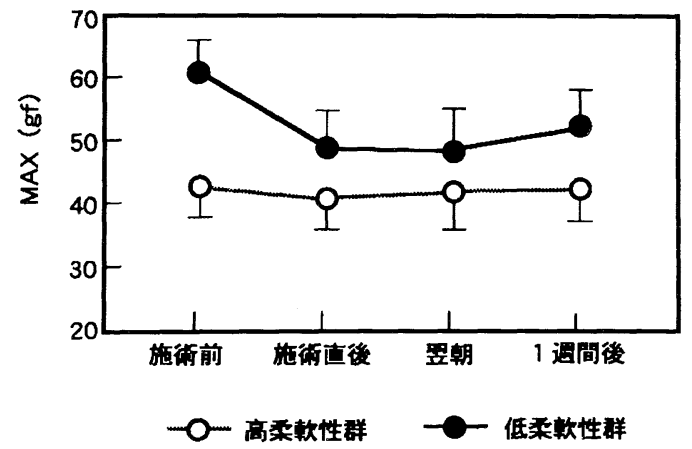

Fig.-6 Changes of MAX parameters after first treatment. Vertical lines in each plot denote $95 \%$ confidence interval .

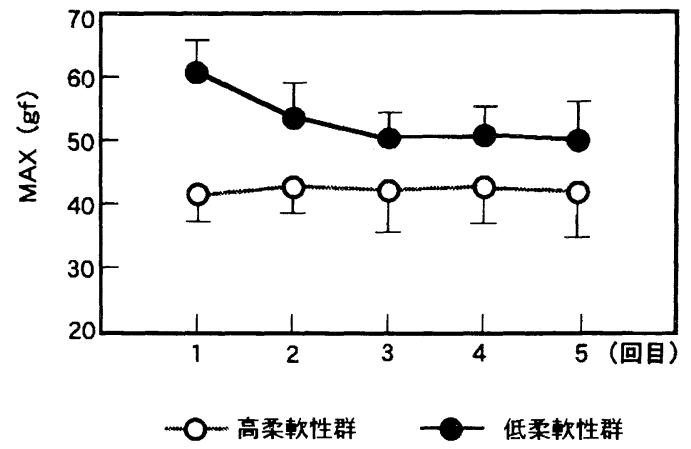

Fig.-7 Changes of MAX parameters for 5 times of treatment (measured before each treatment). Vertical lines in each plot denote $95 \%$ confidence interval .
事実は年齢によって被験者を分類した場合も同様 であり，30代以降の年齢に改善効果が認められ ている。

一方, Fig.-7に示されるように, 5 回の施術毎 の MAX 值の変化を追った場合には, 柔軟性の低 い群に, 改善の傾向がみられる。以上の結果より, フェイシャルトリートメントの柔軟効果は特に施 術直後に顕著であることがわかった。

次に Fig.-8に 1 回目のトリートメントにおけ る H/MAX 值の変化を, Fig.-9に 5 回のトリート メント毎の変化を, 実験前の弾力性指標で層別し た二群について示した。

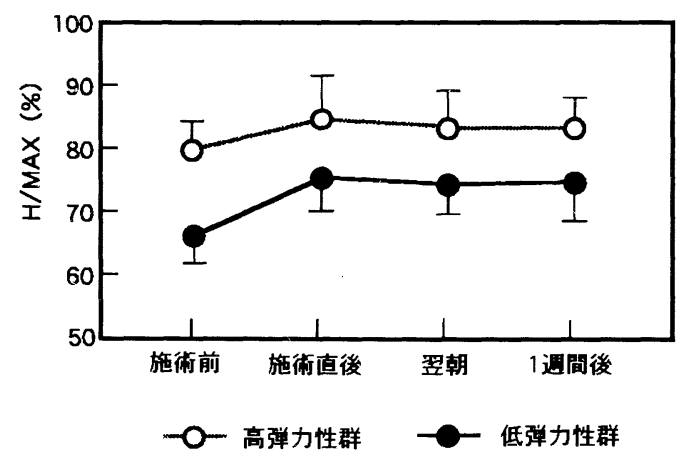

Fig.-8 Changes of MAX parameters after first treatment. Vertical lines in each plot denote $95 \%$ confidence interval .

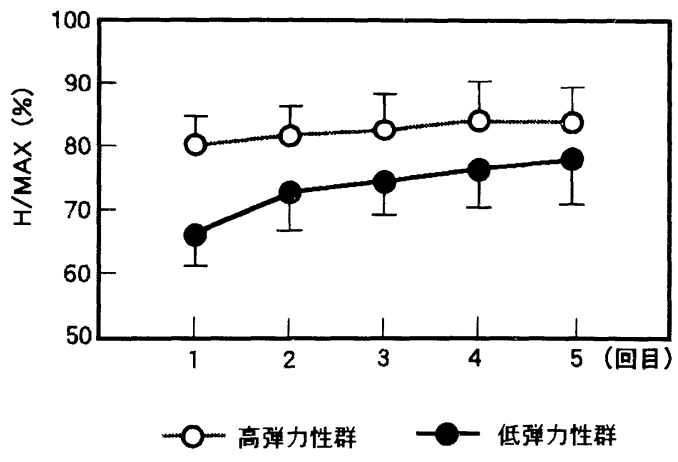

Fig.-9 Changes of MAX parameters for 5 time of treatment (measured before each treatment). Vertical lines in each plot denote $95 \%$ confidence interval . 
Fig.-8において, 施術前と施術直後の H/MAX 值を比較すると, 弾力性の低い群に H/MAX 值の 増加傾向がみられている。

Fig.-9においては, 弾力性の高い群では 4 週間 にわたって弾力性指標の増加が顕著であり, 実験 前と 4 週間後の H/MAX 值に有意差が認められて いる。この事実は年齢によって被験者を分類した 場合も同様であり，30 代以降の年齢に継続使用 効果が認められている。以上をまとめると, 弾力 性の低い群におけるフェイシャルトリートメント の継続使用効果が, 力学的計測によって示された。

以上のように柔軟性評価に関係する比較的表面 の部分の改善には即効性が認められるが, 弾力性 に影響を与えていると考えられる皮下組織や真皮 の力学的性質の改善には一ケ月程度の期間が必要 である。また比較的良好な皮虐生理状態において は改善効果は少なく, ダメージを受けた状態を通 常な状態に近づけることがマッサージの効能であ る。

\section{4. 乳液の触感評価}

\section{1 測定方法}

本実験では, 測定条件は直径 $1 \mathrm{~cm}$ の先端部が球 形のプランジャーを初期圧 $10 \mathrm{~g}$ で接触させ, $5 \mathrm{~mm}$ ／secの速度，30mmのストロークでのプランジン グ（水平方向の移動）を行った。微小変位 $3 \sim 5 \mathrm{~mm}$ (0.6 1.0 sec)におけるデータを高速サンプリング し, 平均值を特性值とした。移動初期のデータは 等速運動でない点, 移動距離 $5 \mathrm{~mm}$ 以上のデー夕は 肌形状が影響するため除外した。

Fig.-10においては乳液塗布時の典型的曲線を 示した。

皮膚表面にトリートメント膜が形成されること によってせん断力が増大しているものと考えられ る。

\section{2 乳液タイプと実験手順}

本実験では成分的に標準タイプとなる以下の既 存製品である 4 品の乳液を使用した。

乳液 1：しっとりしたタイプ

乳液 2: 比較的しっとりしたタイプ

乳液 3: 比較的さっぱりしたタイプ

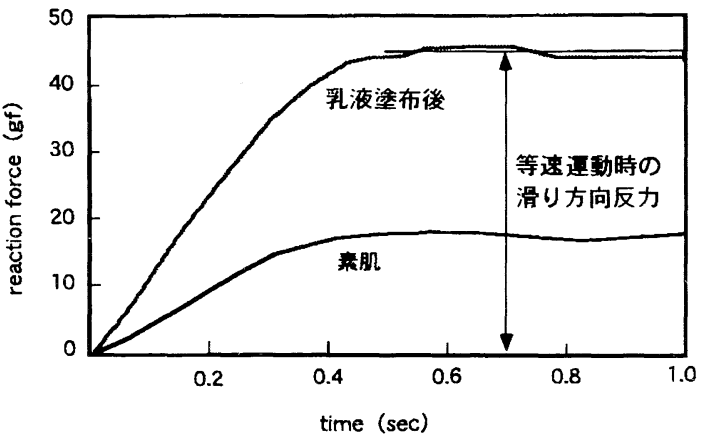

Fig.-10 A change of responce curve afier usage of emulsion

乳液 4:さっぱりしたタイプ

以上の乳液を被験者 4 名(20 25才の女性) が 使用した。実験方法においては, 洗顔 $\rightarrow$ 滑り反力 測定 $\rightarrow$ 乳液使用 $\rightarrow$ 官能評価 $\rightarrow$ 滑り反力測定の順に 実施した。洗顔後は被験後は被験者の肌状態を安 定させるために，30 分間安静状態に保った。乳 液は片側の煩にシリンジで $1 \mathrm{ml}$ 使用し, 使用直 後に官能評価と肌測定を実施した。測定值は使用 前後の変化量を求めて解析した。

\section{3 結果と考察}

滑り反力については, Fig.-10 示したせん断力 の増加傾向が全てのタイプにおいて，観測された。 ここで反力の増加の由来について考えると以下の 3 点が考えられる。

1) 乳液の油分による付着性の増加

2) トリートメント膜形成による摩擦係数の 変化

3) 角層の水分増加によるせん断力の増加 乳液については以上の要因が全て滑り反力の増 大に寄与していると考えられる。1）の要因につ いては油剤の量や種類等の特徴を反映した反力の 変化が観察されている。ここでは，特性值に対す る被験者と乳液の影響について検討するために, 二元配置の分散分析を実施した。解析ソフトウェ アは日本科学技術連盟, 実験データの解析のプロ グラムによる。分散分析結果 Table-1に示した。 被験者，乳液ともに主効果が有意であるが，乳液 の寄与率が高く, 被験者の皮膚状態よりも, 乳液 
Table-1 ANOVA resut of dynamic parameters

分散分析表

\begin{tabular}{|c|c|c|c|c|c|}
\hline 要 & 因 & 平 方 和 & 自由度 & 分 散 & $\mathrm{F}$ 比 \\
\hline 1 & A & 533.3119 & 3 & 177.7706 & 5.2603 \\
\hline 2 & B & 243.5019 & 3 & 81.1673 & 2.4018 \\
\hline 3 & $\mathrm{AB}$ & 304.1506 & 9 & 33.7945 & 1.0000 \\
\hline 全 & 体 & 1080.9644 & 15 & & \\
\hline
\end{tabular}

主効果 ; 水準間の差 $/ \mathrm{t}$ 值

差の標準誤差 $=4.111$

\begin{tabular}{|c|c|c|c|c|}
\hline A 主 効 果 & 1 & 2 & 3 & 4 \\
\hline 5.794 & / & -0.438 & -1.569 & -3.631 \\
\hline $2 \quad 3.994$ & -1.800 & I & -1.131 & -3.193 \\
\hline $3-0.656$ & -6.450 & -4.650 & I & -2.062 \\
\hline $4-9.131$ & -14.925 & -13.125 & -8.475 & / \\
\hline \multicolumn{5}{|l|}{ B 主 効 果 } \\
\hline $1-5.256$ & l & 1.283 & 2.676 & 1.156 \\
\hline $2 \quad 0.019$ & 5.275 & ノ & 1.393 & -0.128 \\
\hline $3 \quad 5.744$ & 11.000 & 5.725 & I & -1.520 \\
\hline $4-0.506$ & 4.750 & -0.525 & -6.250 & / \\
\hline
\end{tabular}

特性值; 滑り反力, 要因 $\mathrm{A}$; 乳液, 要因 $\mathrm{B}$ 被験者

の使用感が反映した特性值であると考えられる。 有意差検定においては，さっぱりタイプの乳液 4 と他のタイプ間で差がみられている。

被験者毎の層別散布図による解析結果を Fig.-11に示した。

しっとり感と滑り反力の対応においては, 被験 者をプーリングすると相関係数は 0.48 と説明力 は不十分であるが, 被験者毎の相関係数を算出す ると0.6 0.9 と相関係数は更に増大する。これは 滑り反力が被験者の皮膚表面特性を反映し, 官能 特性は被験者毎に尺度化されていることを示して いる。

以上よりしっとり感は被験者とすべり反力の 2 つのパラメータによって説明が可能である。被験 者毎の回帰直線の傾きも乳液夕イプにに対するし っとり感の向上が急激な被験者 4 と緩和なその他 の被験者グループに分けられる。このようにスキ ンケアの触感は個人差が大きく, 官能評価を尺度 化するうえで, 本実験で用いたような標準サンプ

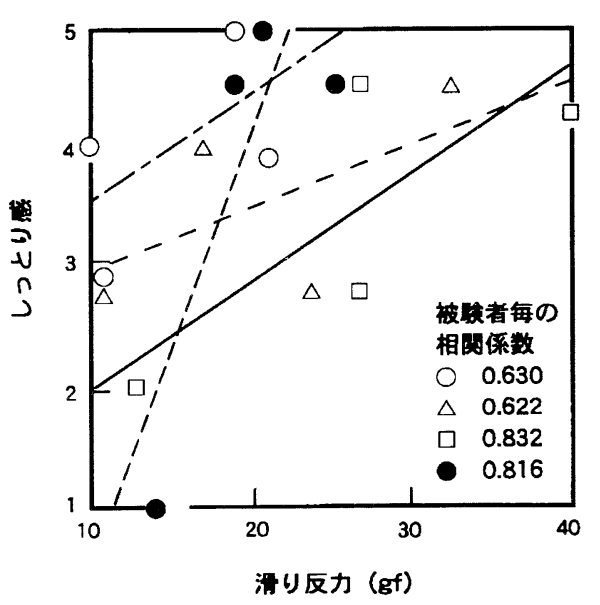

Fig.-11 Corelation analysis between sensory and dynamic parameters/

ルによる補正が必要である。その場合本装置によ る客観的測定を併用することによって, 肌と化粧 料の相互作用が推測できる。 
5. 総 括

本研究で検討した触診の代用化は, トリトーメ ントの効能や使用感を分析し, 計測データとして 表現する観点から有用性が立証された。

具体的には肌表面に対して, 指に相当する触子 を水平方向または垂直方向に移動し, 反力を測定 することによってやわらかさやしっとり感の程度 が推定できる。この場合対応関係に個人の影響が あり，モデル式については，年齢や皮膚生理状態 の因子を加味する必要がある。

測定方法の応用は，のび . ベとつきなどの他の 評価項目に対しても可能であり，触感が重視され る今度のスキンケア製品の開発における客観評価 としての拡張が考えられる。この測定法は比較的 シンプルな触覚モデルから構成され, 機構的には 人間の感覚を十分カバーしうるものとはいえない。 今後はアクチュエーター系の精密化によって, 皮 虐をはじめとした生体系の測定機能を拡張してゆ く予定である。

\section{参考文献}

1) C. Escoffier, "Age Related Mechanical Properties Human Skin : An in-vivo Study", J. of Investigative Dermatology, 93 (3), 353-357 (1989)

2 ) R. Gahame and P. J. T. Holt, “The Influence of Aging on the in-vivo elasticity of human skin", Gerontologica, 15, 121-139 (1969)

3）飯田一郎, 野呂影男, 触覚機能を持つロボット 型測定装置の開発と応用 (第 2 報), 日本化化粧 品技術者会誌, 1993, 27, №.3, 514-523

4 ) 飯田一郎, 井垣嘉之, 桑村泉, 野呂影男, 肌状 態検出における触知覚, 日本機会学会, ロボッ トセンサシンポジウム, 1994, 202-206

5 ）飯田一郎, 藤本雅子, 野吕影男, ヒューマンサ イエンス, ヒトの肌のやわらかさ評価システム に関する研究, 1991,4, No.2, 6-13

\title{
The development and application of evaluation system of the skin surface factility (the third report) $\dagger^{\prime}$
}

\author{
Ichiro Iida $\dagger^{2}$ Akie Tamura $\uparrow^{2}$, Chieko Mizutani $\uparrow^{2}$ and Kageyo Noro $\dagger^{3}$ \\ Product research laboratory, Kose Cosmetics $\dagger^{2}$ \\ School of Human Sciences, Waseda University $\dagger^{3}$
}

\begin{abstract}
In order to analyze the diagnosis information of the physiological human skin condition, a series of tactile and visual evaluation were carried out on the cheeks of 20 panelists by an expert. The corvariances among each evaluation items were examined and two factors, a texture factor and an elasticity factor,were derived. Next, with the view of the estimation of product performance of cosmetics, a measuring device equipped with a robot arm and linear actuator was developed, in order to realize mechanical methods derived from tactile perception models.

This device was applied to evaluate effects of continuous usage of a series of facial treatments. The viscoelastic parameters were derived and the measurement was applied to cheeks of 20 panelists. The significant effects of elasticity were proved after five times of a facial treatment for a month in the higher aged panelists. Next, physiological skin conditions after usaged of emulsions were discussed. Four types of emulsions were used for cheeks of four panelists. Friction forces were measured and from the data analysis of each measurements, the changes of skin surface conditions related to sensory properties of emulsions were detected.
\end{abstract}

